\title{
Rancang Bangun Sistem Minimarket Otomatis Berbasis IoT
}

\author{
Ida Ayu Sri Sinta Anjani ${ }^{1}$, Lie Jasa ${ }^{2}$, I Gusti Agung Putu Raka Agung ${ }^{3}$ \\ [Submission:25-11-2020, Accepted: 27-12-2020]
}

\begin{abstract}
Minimarket provides convenience shopping facilities for customers. But minimarkets still have problems where there are long traffic jams on certain days, thus reducing the time for customers. Therefore, a system that can measure goods and make purchases automatically remotely was developed. The system built using Arduino Mega and Esp8266 as a microcontroller, the sensors used are limit switches, and IR sensors. The movers used in this study are the wiper motor as the $x$-axis driver and the power window motor as the $y$ drive. The servo motor is used as a drive from the door to the room and spiral drive on the food shelf. The research was conducted by making a prototype tool that can communicate with an android application on a smartphone. When a user executes a purchase or picks up goods, the smartphone will send purchase data to the database via a wifi network. The tool is always on standby to collect data from Firebase using the esp8266 as a microcontroller module that can be connected to WiFi. When the data tool is from Firebase, the tool will carry out the execution according to the data received. In the study, the results obtained at the time of taking food were carried out 12 experiments in which the results of the tool could take food according to the input received from the application. In the experiment to collect goods carried out with 12 experiments where the results of the tool can take goods according to the input data received from the application and go to the point of collection. The power consumption required in this design is 2,26 watts on standby, 48,1 watts when taking food, and 106,37 watts when the appliance is moving.
\end{abstract}

Keyword - Aplikasi Android, Arduino Mega,ESP8266, Firebase, Minimarket.

Minimarket memberikan fasilitas belanja dengan kenyamanan untuk pelanggan. Tetapi minimarket masih mempunyai permasalahan dimana terjadi antean yang panjang pada hari atau jam-jam tertentu sehingga mengurangi efisiensi waktu dari pelanggan. Maka dari itu dikembangkan sistem yang dapat memeriksa ketersediaan barang dan melakukan pembelian secara otomatis dari jarak jauh. Sistem yang dibangun menggunakan arduino mega dan esp8266 sebagai microcontroler alat, sensor yang digunakan adalah limit switch, dan ir sensor. Penggerak yang digunakan pada penelitian ini adalah motor wiper sebagai penggerak sumbu $\mathrm{x}$ dan motor power window sebagai penggerak $y$. Motor servo digunakan sebagai penggerak dari pintu ruangan dan penggerak spiral pada rak makanan. Penelitian dilakukan dengan membuat

${ }^{1}$ Mahasiswa,Program Studi Teknik Elektro Fakultas Teknik Universitas Udayana, Jalan dewi sri V, Batubulan 80231. Indonesia (telp: 0361-123445;e-mail:dayusintaanjani77@gmail. com)

${ }^{2,3}$ Dosen,Program Studi Teknik Elektro Fakultas Teknik Universitas Udayana, Jln. Jalan Kampus Bukit Jimbaran 80361 INDONESIA (telp: 0361-703315; fax: 0361-4321; e-mail: liejasa@unud.ac.id, rakaagung@unud.ac.id)

Ida Ayu Sri Sinta Anjani : Rancang Bangun isitem Minimarket... sebuah prototype alat yang bisa berkomunikasi dengan aplikasi android pada smartphone. Ketika pengguna melakukan eksekusi pembelian atau pengambilan barang, smartphone akan mengirimkan data pembelian ke firebase melalui jaringan wifi. Alat selalu standby mencuplik data dari firebase menggunakan esp8266 sebagai modul mikrokontroler yang dapat terhubung dengan wifi. Ketika alat menerima data dari firebase maka alat akan melakukan eksekusi sesuai data yang diterima. Pada penelitian didapatkan hasil pada saat pengambilan makanan, dilakukan 12 percobaan dimana didapatkan hasil alat dapat melakukan pengambilan makanan sesuai dengan input yang diterima dari aplikasi. Pada percobaan pengambilan barang dilakukan dengan 12 percobaan dimana didapatkan hasil alat dapat melakukan pengambilan barang sesuai data input yang diterima dari aplikasi dan menuju titik pengambilan. Konsumsi daya yang diperlukan pada rancang bangun ini adalah 2,26 watt saat standby, 48,1 watt saat pengambilan makanan, dan 106,37 watt saat alat bergerak.

Kata Kunci- Aplikasi Android, Arduino Mega,ESP8266, Firebase, Minimarket.

\section{PENDAHULUAN}

Minimarket adalah toko swalayan yang hanya memiliki satu atau dua mesin register sementara supermarket adalah swalayan besar yang juga menjual barang-barang segar seperti sayur dan daging dengan jumlah mesin register lebih besar dibanding dengan minimarket. minimarket sebagai ritel modern berpengaruh pada perubahan sosial, ekonomi masyarakat dan tata lingkungan[1]. Misi dari minimarket adalah memberikan pelayanan belanja pada masyarakat dengan kantong relatif kecil tapi dengan kenyamanan yang sama dengan supermarket. Kelebihan pemanfaatan smartphone adalah dapat digunakan pada berbagai kegiatan seperti chatting, sosial media, browsing, game online maupun online shopping[2]. Hal tersebut mengakibatkan pasar mengalami perkembangan dari waktu ke waktu. Dari yang bersifat tradisional menjadi modern[3]. Keberadaan pasar modern ini tidak dapat dibendung seiring dengan perubahan pemikiran dan prilaku konsumsi masyarakat[4]. Keberadaan pasar moderen juga berdampak pada berkurangnya minat belanja pada pasar tradisional[5].

Seiring perkembangan pasar modern, terdapat permasalahan pada pasar modern. Permasalahan yang sering terjadi diantaranya antrean dari pembeli yang sangat panjang ketika berbelanja pada jam atau hari-hari tertentu pada minimarket yang menjual barang yang lengkap. Permasalahan yang kedua pada sistem penjualan konvensional, pembeli yang tidak mengetahui stok barang yang terdapat pada minimarket tersebut apakah masih tersedia atau tidak sehingga pembeli yang pergi ke minimarket untuk membeli hanya satu

$$
\text { p-ISSN:1693 - 2951; e-ISSN: 2503-2372 }
$$


atau beberapa barang saja akan mengalami rugi waktu dan tenaga. internet merupakan sebuah sistem jaringan komputer yang dapat saling terhubung secara global untuk dapat berkomunikasi dengan perangkat diseluruh dunia[6]. Internet of thing merupakan salah satu konsep yang mengusung kemampuan komunikasi data informasi maupun sensor melalui jaringan internet[7].

Oleh karena itu dikembangkan sebuah sistem baru yang berjudul "Rancang Bangun Sistem Minimarket Otomatis Berbasis IOT”. Tujuan dari penelitian ini dapat membuat prototype dan aplikasi android yang dapat melakukan pembelian dan pengambilan barang dengan menggunakan mikrokontroler arduino mega 2560 dan ESP8266 dimana dapat berkomunikasi antara prototype dan aplikasi android untuk melakukan eksekusi pembelian dan pengambilan barang. Alat yang akan dikembangkan menggunakan ESP8266 dan Arduino Mega 2560 sebagai mikrokontroler utama, Limit switch sebagai sensor pada prototype, Motor wipper sebagai aktuator dari pergerakan pada sumbu Y, Motor power window sebagai aktuator dari pergerakan pada sumbu $\mathrm{X}$, Motor Servo sebagai aktuator dari sistem vending machine, Firebase sebagai tempat menyimpan data dari sistem, dan Smartphone android sebagai wadah aplikasi dari sistem minimarket otomatis. Alat ini dapat mengatasi permasalahan antrian pelanggan yang banyak dan lama, Permasalahan Stok barang yang habis, Efisiensi waktu yang lebih baik karena pelanggan bisa memesan barang yang ingin dibeli dari mana saja.

\section{KAJIAN PUSTAKA}

\section{A. $\quad$ ESP8266}

ESP8266 adalah sebuah modul WiFi yang akhir-akhir ini semakin digemari para hardware developer. Selain karena harganya yang sangat terjangkau, modul WiFi serbaguna ini sudah bersifat SoC (System on Chip), sehingga kita bisa melakukan programming langsung ke ESP8266 tanpa memerlukan mikrokontroller tambahan[8]. NodeMCU ESP8266 merupakan modul wifi yang dilengkapi GPIO, ADC,UART, dan PWM[9]. NodeMCU merupakan sebuah open source platform IoT dan pengembangan kit yang menggunakan bahasa pemrograman Lua untuk membantu dalam membuat prototype produk IoT atau bisa dengan memakai sketch dengan adruino IDE[10]. Pengembangan kit ini didasarkan pada modul ESP8266, yang mengintegrasikan GPIO, PWM (Pulse Width Modulation), IIC, 1-Wire dan ADC (Analog to Digital Converter) semua dalam satu board. NodeMCU berukuran panjang $4.83 \mathrm{~cm}$, lebar $2.54 \mathrm{~cm}$, dan berat 7 gram. Board ini sudah dilengkapi dengan fitur WiFi dan Firmware-nya yang bersifat opensource[11].

\section{B. Arduino Mega 2560}

Arduino adalah Board berbasis mikrokontroler atau papan rangkaian elektronik open source yang di dalamnya terdapat komponen utama yaitu sebuah chip mikrokontroler dengan jenis AVR dari perusahaan Atmel[12]. Mikrokontroler itu sendiri adalah chip atau IC (integrated circuit) yang bisa diprogram menggunakan computer. Tujuan menanamkan program pada mikrokontroler adalah agar rangkaian elektronik dapat membaca input, memproses input tersebut dan kemudian menghasilkan output sesuai yang diinginkan[13]. Jadi mikrokontroler bertugas sebagai otak yang mengendalikan proses input, dan output sebuah rangkaian elektronik[14]. Arduino Mega 2560 memiliki kelebihan dibandingkan dengan arduino Uno karena jumlah pin yang terdapat pada Arduino Mega 2560 lebih banyak dari pada arduino uno[15].

\section{Firebase}

Firebase adalah salah satu layanan dari google yang berfungsi untuk mempermudah pengembangan aplikasi aplikasi dalam pengembangan untuk android, IOS maupun WEB[16]. firebase memiliki beberapa fitur yang sering digunakan oleh pengembang seperti Authentication, Hosting, Cloud Storage, dan Realtime Database. firebase digunakan karena penggunaanya yang mudah dan mempunyai referensi yang banyak dapat ditemui di internet maupun di dokumentasi yang diberikan oleh firebase. Firebase adalah salah satu platform yang diperuntukan untuk aplikasi realtime baik website ataupun mobile[17].

\section{Thunkable}

Thunkable adalah salah satu aplikasi atau tools IDE open sourse dimana thunkable tersedia untuk pembuatan aplikasi jenis mobile yaitu android dan IOS dalam keperluan programmer atau mobile developer. thunkable memberikan kemudahan dalam pembuatan aplikasi android maupun IOS karena dalam perancangan interface digunakan sistem drag and drop elemen pallete dan untuk sistem pemrogramannya digunakan sistem pembuatan kode yang disebut block yang juga menggunakan sistem drag and drop [18].

\section{Metodologi Penelitian}

A. Metode penelitian sistem minimarket otomatis dilakukan dengan beberapa perancangan alat sesuai dengan yang diinginkan. Berikut gambar 2 diagram alir pada alat sistem minimarket otomatis.

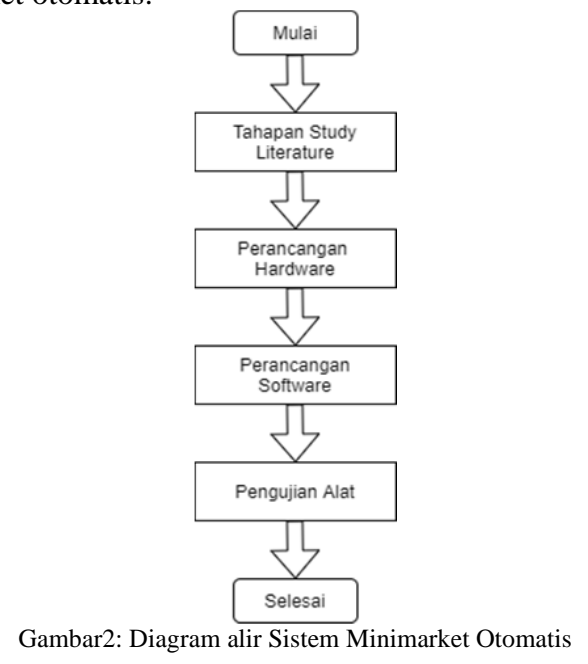

Tahap perancangan dari Sistem minimarket Otomatis Berbasis IOT dimulai dari tahapan literature, perancangan hardware, perancangan software, sampai dengan uji coba. Tahap awal sebelum melakukan perancangan alat, dilakukan 


\section{B. Diagram Blok Sistem Minimarket Otomatis Berbasis IOT}

Sebelum dilakukannya perancangan pada hardware dan software, terlebih dulu ditentukan diagram blok kerja alat yang akan dibuat untuk mempermudah perancangan tersebut.

1) Diagram Blok hardware Sistem minimarket Otomatis Berbasis IOT

Pada diagram blok hardware dibagi menjadi 3 bagian yaitu input, pemrosesan, dan output. Gambar 3 menunjukkan diagram blok hardware dari Sistem minimarket Otomatis Berbasis IOT.

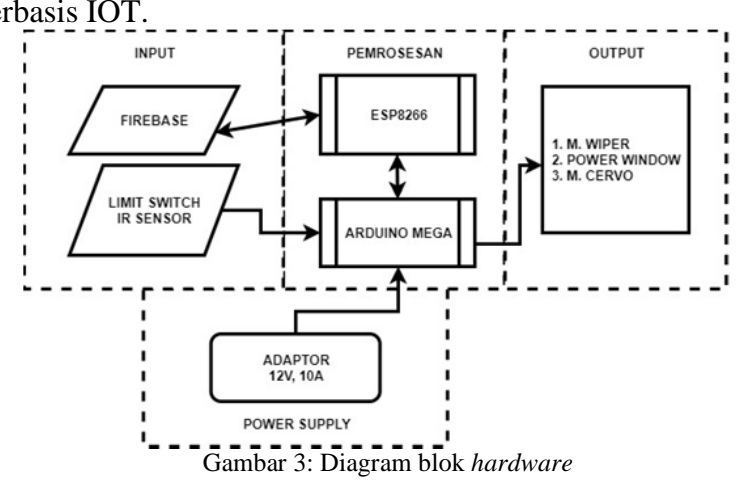

2) Diagram Blok software Sistem minimarket Otomatis Berbasis IOT

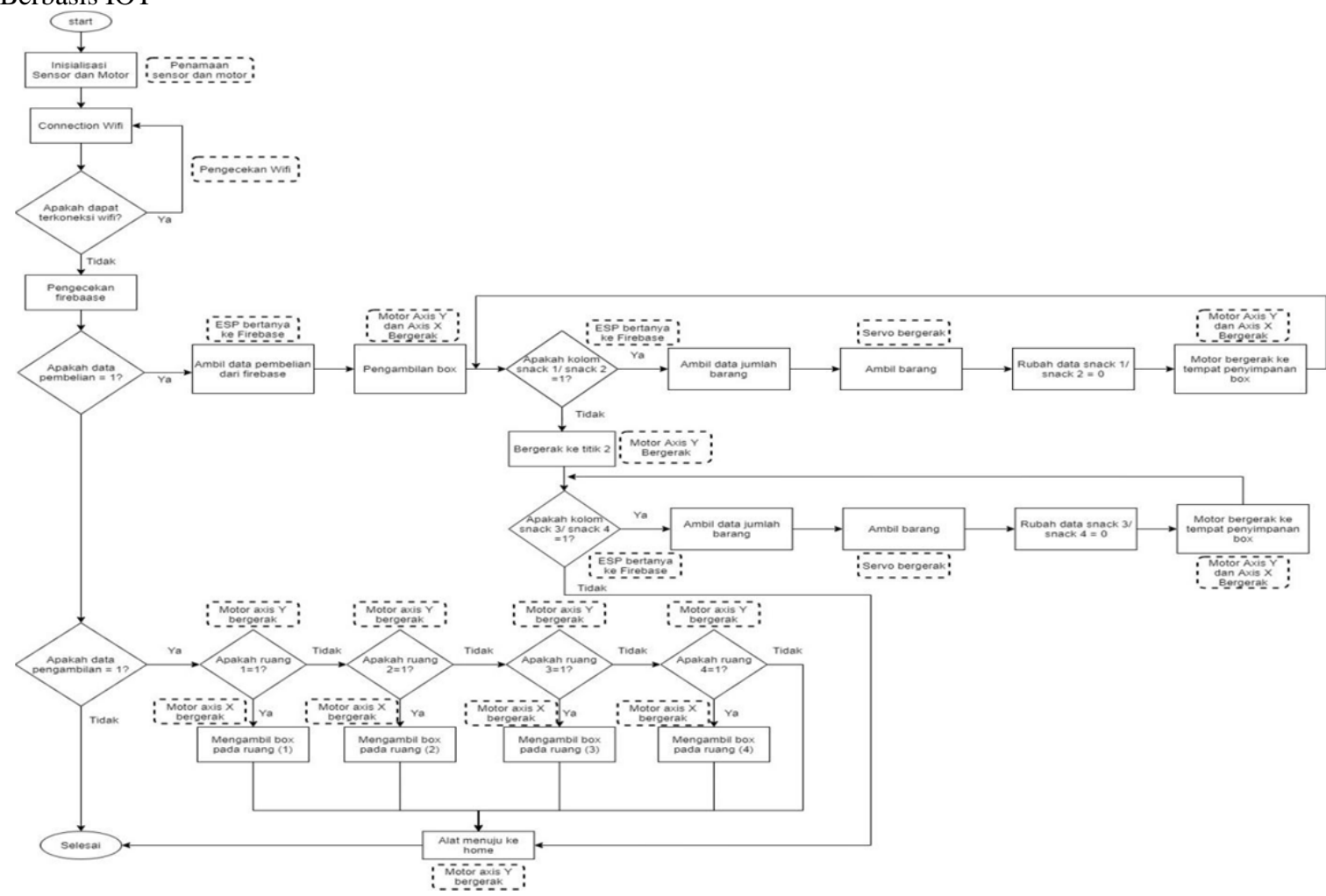

Gambar 5: Flowchart alat Sistem minimarket Otomatis Berbasis IOT

Ida Ayu Sri Sinta Anjani : Rancang Bangun isitem Minimarket...

p-ISSN:1693 - 2951; e-ISSN: 2503-2372 
Dapat dilihat pada Gambar 5 ditunjukan hal pertama yang dilakukan adalah inisialisasi port dari sensor dan motor. Selanjutnya dilakukan proses meghubungkan alat dengan internet dan database. Ketika alat dapat terhubung dengan internet maka alat akan melakukan pengecekan pada data di firebase. Ketika data pembelian pada firebase bernilai 1 maka alat akan memproses data dan melakukan cek data pada data snack yang bernilai satu. Ketika selesai melakukan cek data , maka motor pada alat akan bergerak menuju koordinat dari data snack yang bernilai 1 dan memutar motor servo untuk menjatuhkan snack. Ketika pengambilan snack telah selesai maka alat akan bergerak ke tempat penyimpanan untuk meletakan box yang telah diisi oleh snack.

Ketika data pengambilan barang pada firebase bernilai 1 maka ESP8266 akan melakukan cek pada firebase untuk mendapatkan data ruangan penyimpanan mana yang bernilai
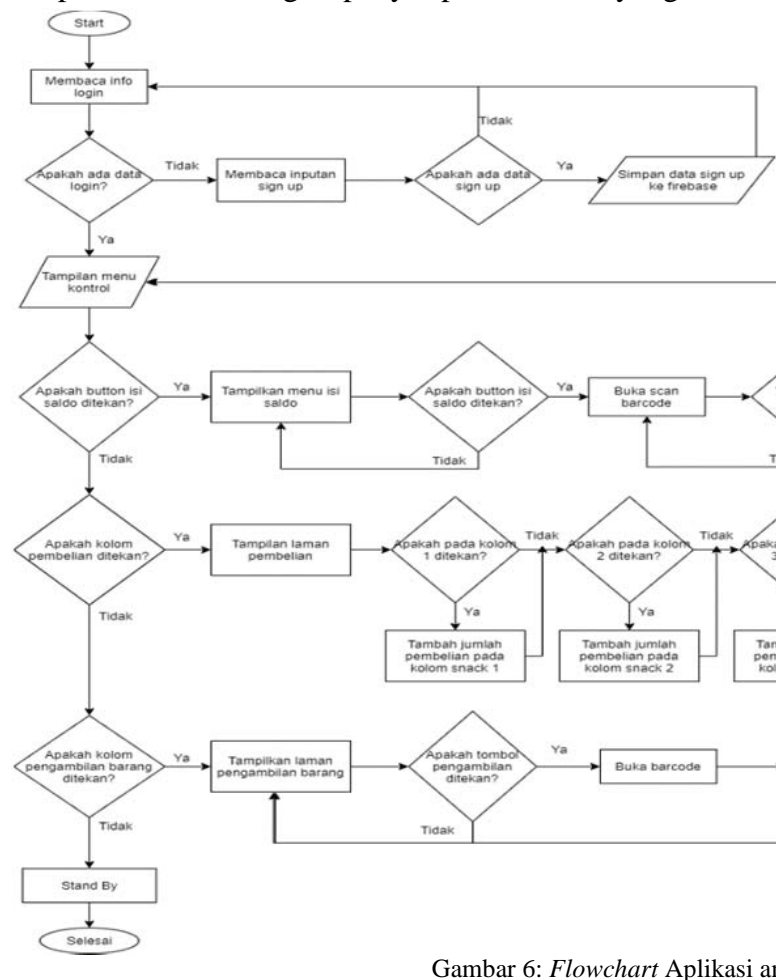

1. Ketika data ruang penyimpanan yang bernilai 1 telah ditemukan, maka alat akan menggerakan motor untuk menuju koordinat yang dituju dan mengambil box pada tempat penyimpanan tersebut untuk dibawa kembali ke koordinat HOME. Ketika data dari pembelian dan pengambilan snack pada firebase bernilai 0 , maka alat akan standby dan terus menerus melakukan cek data pada firebase.

\section{2) Flowchart Aplikasi android Sistem minimarket Berbasis} IOT

Diagram alir (flowchart) pada pembuatan aplikasi android untuk sistem minimarket berbasis IOT berfungsi untuk mempermudah dalam perancangan dan pembuatan aplikasi android untuk sistem minimarket berbasis IOT. Flowchart dari aplikasi android sistem minimarket berbasis IOT dapat dilihat pada Gambar 6.
Pada tahap pertama akan dilakukan pembacaan data pada LOGIN ketika user mengetik data akun pada kolom LOGIN maka aplikasi akan memproses data tersebut. Ketika ada data LOGIN maka aplikasi akan melakukan pengecekan apakah data akun tersebut terdaftar pada firebase. Ketika data akun yang dimasukan tidak terdaftar pada firebase maka akan menuju SIGN UP untuk melakukan daftar akun. Ketika data akun yang dimasukan terdaftar pada firebase maka user dapat masuk ke aplikasi dan masuk ke menu kontrol. Pada menu kontrol terdapat 3 button pilihan yaitu button “ isi saldo”, “ pembelian”,”pengambilan”. Ketika button "isi saldo “ ditekan maka akan menuju ke laman isi saldo dimana aplikasi akan membuka scan barcode untuk melakukan scan pada voucher.

Ketika barcode ditemukan dan data dari barcode adalah benar, maka data barcode akan ditambahkan pada saldo pengguna. Ketika tombol pembelian ditekan maka aplikasi akan menuju laman pembelian. Pada laman pembelian terdapat 4 pilihan barang yang dapat dibeli pada saat tombol barang ditekan maka , data jumlah barang akan ditambahkan. Ketika tombol selesai ditekan maka akan menuju laman bayar. Ketika tombol bayar ditekan maka saldo akan dikurangkan dan data pembelian akan disimpan pada firebase.

Ketika tombol pengambilan ditekan maka aplikasi akan menuju laman pengambilan barang. Pada laman pengambilan barang bila tombol "ambil barang" ditekan maka akan membuka fungsi scan barcode. Ketika data hasil scan barcode sama dengan data kode pengambilan barang pada firebase , maka aplikasi akan mengirim data pengambilan barang ke firebase untuk selanjutnya diteruskan ke alat untuk mengeluarkan barang yang telah dipesan sebelumnya.

D. Rancangan hardware Keseluruhan

Rancangan hardware Keseluruhan bertujuan untuk memperlihatkan keseluruhan rangkaian hardware yang 
Majalah Ilmiah Teknologi Elektro, Vol. 19, No. 2, Juli - Desember 2020

DOI: https://doi.org/10.24843/MITE.2020.v19i02.P19

dipakai pada sistem minimarket otomatis berbasis IOT. Rancangan hardware keseluruhan juga digunakan untuk mempermudah dalam pembuatan dan peletakan komponen pada PCB saat proses perancangan layout Rangkaian. Gambar 7 dan 8 merupakan rangkaian dari keseluruhan sistem yang digunakan pada Sistem minimarket Otomatis Berbasis IOT.

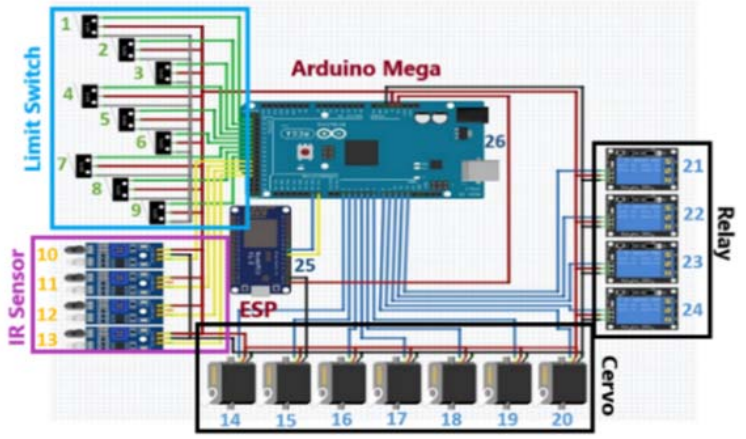

Gambar 7: Rancangan hardware Keseluruhan Sistem

Konfigurasi dari konektivitas PIN antara rangkaian Keseluruhan Sistem dapat dilihat pada Tabel 2:

TABEL II

KONEKSI PIN RANGKAIAN KESELURUHAN SISTEM

\begin{tabular}{|c|c|c|c|}
\hline No & Keterangan Komponen & $\begin{array}{c}\text { No } \\
\text { Komponen }\end{array}$ & $\begin{array}{c}\text { Pin Arduino } \\
\text { Mega }\end{array}$ \\
\hline \multirow{9}{*}{1} & \multirow{9}{*}{ Limit Switch } & 1 & 53 \\
\hline & & 2 & 51 \\
\hline & & 3 & 49 \\
\hline & & 4 & 47 \\
\hline & & 5 & 45 \\
\hline & & 6 & 43 \\
\hline & & 7 & 41 \\
\hline & & 8 & 39 \\
\hline & & 9 & 37 \\
\hline \multirow{4}{*}{2} & \multirow{4}{*}{ Infrared Sensor } & 10 & 35 \\
\hline & & 11 & 33 \\
\hline & & 12 & 31 \\
\hline & & 13 & 29 \\
\hline \multirow{2}{*}{3} & \multirow{2}{*}{ ESP8266 } & 25 & 14 \\
\hline & & 26 & 15 \\
\hline \multirow{4}{*}{4} & \multirow{4}{*}{ Servo SG 90 Makanan } & 14 & 2 \\
\hline & & 15 & 3 \\
\hline & & 16 & 4 \\
\hline & & 17 & 5 \\
\hline \multirow{3}{*}{5} & \multirow{2}{*}{$\begin{array}{c}\text { Servo SG } 90 \text { Palang Pintu } \\
\text { Penyimpanan }\end{array}$} & 18 & 6 \\
\hline & & 19 & 7 \\
\hline & Servo SG 90 Box Holder & 20 & 8 \\
\hline \multirow{4}{*}{6} & \multirow{4}{*}{ Relay } & 21 & 9 \\
\hline & & 22 & 10 \\
\hline & & 23 & 11 \\
\hline & & 24 & 12 \\
\hline \multirow{2}{*}{7} & \multirow[t]{2}{*}{ Regulator } & Vcc & $5 \mathrm{~V}$ \\
\hline & & Gnd & Gnd \\
\hline
\end{tabular}

Pada PCB nantinya infared sensor, limit switch dan Servo menggunakan socket white housing sebagai penghubung untuk mempermudah dalam penelitian dan pemasangan dari sistem minimarket otomatis berbasis IOT.

\section{HASIL DAN PEMBAHASAN}

\section{A. Realisasi Hasil Perancangan Sistem Minimarket Otomatis}

Sistem Minimarket Otomatis Berbasis IOT yang dirancang pada penelitian ini digunakan Arduino Mega dan ESP8266 sebagai otak dari keseluruhan sistem. Arduino mega akan memproses data yang diterima pada bagian pin input yang berasal dari data firebase maupun limit switch Ida Ayu Sri Sinta Anjani : Rancang Bangun isitem Minimarket... untuk diproses dan kemudian menghasilkan output data maupun gerakan yang diinginkan. Firebase digunakan sebagai database dari pengguna alat yang diperlukan oleh ESP8266 dan berfungsi juga sebagai output dari ESP8266 hasil pemrosesan atau pengontrolan dari ESP8266 disimpan kembali di firebase.

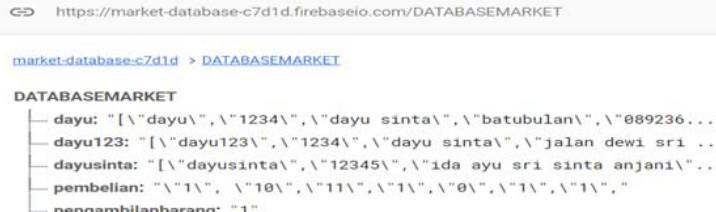

Gambar 8 Tampilan Database Sistem Minimarket Otomatis Berbasis IoT

Realisasi dari alat sistem minimarket otomatis, ditunjukan pada gambar 9 dan 10 berikut

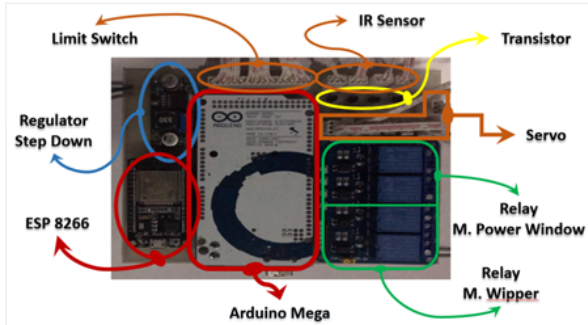

Gambar 9 Realisasi bagian Elektronika dari Sistem Minimarket Otomatis

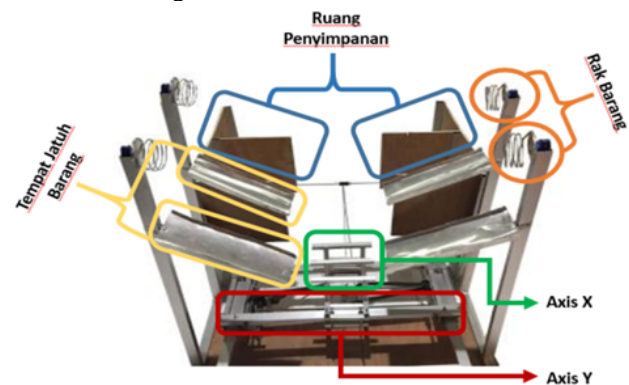

Gambar 10 Realisasi bagian Mekanik dari Sistem Minimarket Otomatis

Gambar 9 dan 10 merupakan bagian mekanik dari Sistem Minimarket Otomatis. Pada mekanik akan terpasang komponen elektronika yang sudah tersedia seperti, IR Sensor, Limit Switch, Motor Wipper, Power Window, Motor Cervo, ESP8266, Arduino Mega, dan Adaptor sesuai dengan titik point yang sudah ditentukan. Spesifikasi dari realisasi alat sistem minimarket otomatis ditunjukan pada tabel 3 berikut:

TABEL III

SPESIFIKASI ALAT SISTEM MINIMARKET OTOMATIS

\begin{tabular}{|l|l|}
\hline Spesifikasi & Keterangan \\
\hline Panjang rangka & $150 \mathrm{~cm}$ \\
\hline Lebar rangka & $60 \mathrm{~cm}$ \\
\hline Tinggi rangka & 2 axis \\
\hline Tegangan Input & 12 Volt \\
\hline Arus Maksimal & 10 Ampere \\
\hline Motor pergerakan sumbu $x$ & Motor Power Window \\
\hline Motor pergerakan sumbu y & Motor Wipper \\
\hline Sensor titik lokasi pergerakan & Limit Switch \\
\hline Dimensi Ruangan Penyimpanan & $30 \mathrm{~cm}$ x 30 cm \\
\hline Dimensi perosotan Barang & $40 \mathrm{~cm}$ x 20 cm \\
\hline Motor penggerak penjatuh makanan & Motor Servo SG90 \\
\hline Ukuran box & $10 \mathrm{~cm}$ x 10 cm \\
\hline
\end{tabular}

p-ISSN:1693 - 2951; e-ISSN: 2503-2372 


\section{B. Pengujian dan Pembahasan Sistem Pembelian Barang pada Alat}

Pengujian sistem pembelian barang pada alat bertujuan untuk menguji sistem berjalan dengan baik dalam mengambil box/keranjang yang terdapat pada ruang penyimpanan, menguji prototype dalam mengambil produk yang dibeli oleh pelanggan, dan menguji prototype dalam menempatkan kembali box/keranjang sesuai dengan tempat pengambilan box/keranjang sebelumnya.

1) Uji coba pergerakan alat ke titik pembelian

Pada ujicoba pergerakan alat ke titik pembelian dilakukan dengan uji coba titik berhenti dari alat apakah sudah sesuai atau tidak dengan keluaran yang diinginkan. Hasil uji coba pergerakan alat ke titik pembelian dapat dilihat pada tabel 4.

TABEL IV

UJI COBA PERGERAKAN ALAT KE TITIK PEMBELIAN

\begin{tabular}{|c|c|c|c|c|c|c|c|}
\hline \multirow[t]{2}{*}{ Percobaan } & \multicolumn{2}{|c|}{$\begin{array}{l}\text { Berhenti di Titik } \\
1\end{array}$} & \multicolumn{2}{|c|}{ Berhenti di titik 2} & \multicolumn{2}{|c|}{$\begin{array}{l}\text { Menuju Ruang } \\
\text { Penyimpanan }\end{array}$} & \multirow[t]{2}{*}{ Ket } \\
\hline & Ya & & Ya & Tidak & Ya & Tidak & \\
\hline $\begin{array}{l}\text { Tidak Melakukan } \\
\text { Pembelian }\end{array}$ & & $\checkmark$ & & $\checkmark$ & & 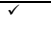 & Berhasil \\
\hline $\begin{array}{l}\text { Pembelian } \\
\text { barang a }\end{array}$ & $\checkmark$ & & & $\checkmark$ & $\checkmark$ & & Berhasil \\
\hline $\begin{array}{l}\begin{array}{l}\text { Pembelian } \\
\text { barang b }\end{array} \\
\end{array}$ & $\checkmark$ & & & $\checkmark$ & $\checkmark$ & & Berhasil \\
\hline $\begin{array}{l}\text { Pembelian } \\
\text { barang a dan b }\end{array}$ & $\checkmark$ & & & $\checkmark$ & $\checkmark$ & & Berhasil \\
\hline $\begin{array}{l}\text { Pembelian } \\
\text { barang c }\end{array}$ & & $\checkmark$ & $\checkmark$ & & 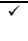 & & Berhasil \\
\hline $\begin{array}{l}\text { Pembelian } \\
\text { barang d }\end{array}$ & & $\checkmark$ & 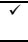 & & $\checkmark$ & & Berhasil \\
\hline $\begin{array}{l}\text { Pembelian } \\
\text { barang c dan d }\end{array}$ & & $\checkmark$ & 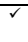 & & $\checkmark$ & & Berhasil \\
\hline $\begin{array}{l}\text { Pembelian } \\
\text { barang a dan c }\end{array}$ & $\checkmark$ & & $\checkmark$ & & $\checkmark$ & & Berhasil \\
\hline $\begin{array}{l}\begin{array}{l}\text { Pembelian } \\
\text { barang a dan d }\end{array} \\
\end{array}$ & $\checkmark$ & & $\checkmark$ & & $\checkmark$ & & Berhasil \\
\hline $\begin{array}{l}\text { Pembelian } \\
\text { barang b dan } \mathrm{c}\end{array}$ & $\checkmark$ & & $\checkmark$ & & $\checkmark$ & & Berhasil \\
\hline $\begin{array}{l}\text { Pembelian } \\
\text { barang b dan d }\end{array}$ & $\checkmark r$ & & $a^{2}$ & & $\checkmark$ & & Berhasil \\
\hline $\begin{array}{l}\text { Pembelian } \\
\text { barang a,b,c dan } \\
\text { d }\end{array}$ & $\checkmark$ & & $\checkmark$ & & $\checkmark$ & & Berhasil \\
\hline
\end{tabular}

Berdasarkan data percobaan uji coba pergerakan alat ke titik pembelian yang ditunjukan pada tabel 4 dapat dinyatakan bahwa alat melakukan pergerakan dan berhenti di titik 1 jika dilakukan pembelian barang a atau b, dan akan berhenti di titik 2 jika dilakukan pembelian barang c atau d. Ini berarti motor wiper bergerak lalu berhenti di titik 1 ketika limit switch 1 tertekan dan berhenti di titik 2 ketika limit switch 2 tertekan. Alat akan bergerak keruang penyimpanan ketika seluruh ir sensor bernilai 0 atau semua makanan telah diambil. Berdasarkan penelitian tersebut dapat disimpulkan bahwa penelitian pergerakan alat ke titik pembelian bekerja sesuai rencana.

2) Uji coba pengambilan barang dari rak makanan

Pada ujicoba pengambilan barang dari rak makanan dilakukan dengan menganalisa apakah rak yang bergerak dan makanan yang jatuh sudah sesuai dengan pembelian yang dilakukan. Hail uji coba pengambilan barang dari rak makanan dapat dilihat pada tabel 5 .

$$
\text { TABEL V }
$$

UJI COBA PENGAMBILAN BARANG DARI RAK MAKANAN

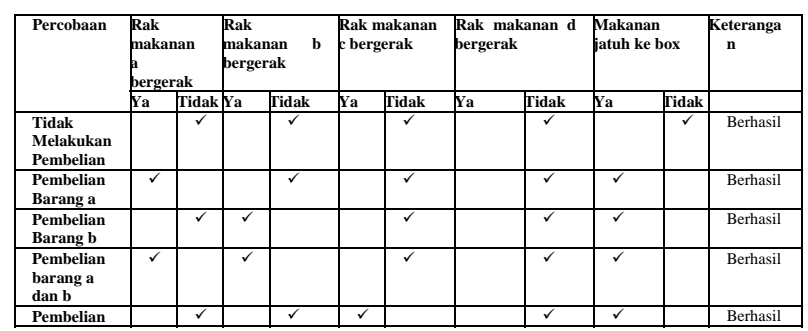

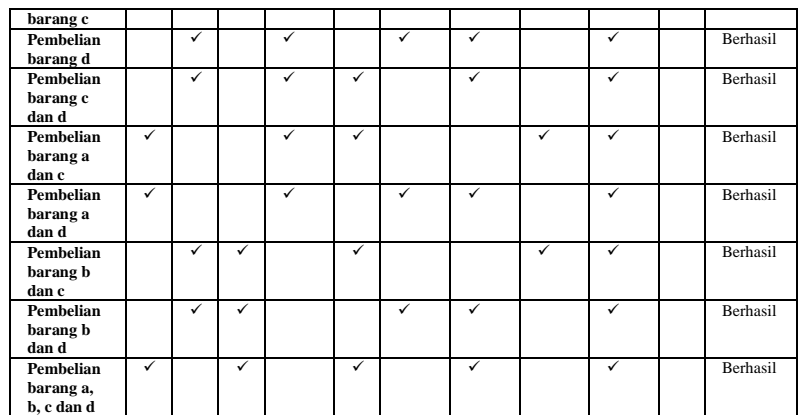

Dapat dilihat pada tabel 5 dimana diuji coba pengambilan barang dari rak makanan. Berdasarkan tabel 5 tersebut dapat disimpulkan pergerakan rak makanan ketika ada perintah pembelian dari barang barang tertentu. Pada uji coba pegambilan barang dari rak makanan dilakukan dengan melakukan 12 percobaan berbeda.

3) Uji coba penyimpanan barang ke ruang penyimpanan

Pada ujicoba penyimpanan barang ke ruang penyimpanan dilakukan dengan menganalisa apakah barang yang telah diambil dapat dimasukan ke ruang penyimpanan sesuai dengan perintah yang diinginkan. Hasil uji coba pengambilan barang dari rak makanan dapat dilihat pada tabel 6 .

TABEL VI

UJI COBA PENYIMPANAN BARANG KE RUANG PENYIMPANAN

\begin{tabular}{|l|l|l|l|l|l|l|l|l|l|}
\hline \multirow{2}{*}{$\begin{array}{l}\text { Kode } \\
\text { Ruang }\end{array}$} & \multicolumn{2}{|l|}{$\begin{array}{l}\text { Masuk ruang } \\
\text { Penyimpanan 1 }\end{array}$} & \multicolumn{2}{|l|}{$\begin{array}{l}\text { Masuk ruang } \\
\text { Penyimpanan 2 }\end{array}$} & \multicolumn{2}{|l|}{$\begin{array}{l}\text { Masuk ruang } \\
\text { Penyimpanan 3 }\end{array}$} & \multicolumn{2}{l|}{$\begin{array}{l}\text { Masuk ruang } \\
\text { Penyimpanan 4 }\end{array}$} & Ket \\
\cline { 2 - 10 } & Ya & Tidak & Ya & Tidak & Ya & Tidak & Ya & Tidak & \\
\hline 001 & $\checkmark$ & $\checkmark$ & & $\checkmark$ & & $\checkmark$ & & $\checkmark$ & Berhasil \\
\hline 002 & & $\checkmark$ & $\checkmark$ & & & $\checkmark$ & & $\checkmark$ & Berhasil \\
\hline 003 & & $\checkmark$ & & $\checkmark$ & $\checkmark$ & & & $\checkmark$ & Berhasil \\
\hline 004 & & $\checkmark$ & & & & $\checkmark$ & & Berhasil \\
\hline
\end{tabular}

Dapat dilihat seperti tabel 6 dimana dilakukan percobaan penyimpanan barang ke ruang penyimpanan sebanyak 4 percobaan yaitu perocobaan penyimpanan dengan kode ruangan 001, 002, 003 dan 004. Dapat dianalisa ketika percobaan penyimpanan ruang dengan kode 001, alat bergerak dan masuk kedalam ruang penyimpanan 1 dan tidak memasuki ruang penyimpanan lainnya. ketika percobaan penyimpanan ruang dengan kode 002, alat bergerak dan masuk kedalam ruang penyimpanan 2. ketika percobaan penyimpanan ruang dengan kode 003 , alat bergerak dan masuk kedalam ruang penyimpanan 3. ketika percobaan penyimpanan ruang dengan kode 004, alat bergerak dan masuk kedalam ruang penyimpanan 4. Dari keempat percobaan penyimpanan tersebut, dapat disimpulkan bahwa barang masuk ke ruang penyimpanan sesuai dengan kode penyimpanan yang diperintahkan, dan percobaan penyimpanan barang ke ruang penyimpanan dapat dikatakan berhasil.

\section{Pengujian dan Pembahasan Sistem Pengambilan Barang pada Alat}

Pengujian sistem pengambilan barang bertujuan untuk menguji sistem berjalan dengan baik dalam mengambil barang yang sudah dibeli oleh pelanggan sesuai dengan ruang penyimpanan yang ditentukan oleh sistem agar mempermudah pelanggan dalam mengambil barang yang sudah dibeli pada minimarket tersebut. Setelah melakukan scan barcode dan data yang terdapat pada database sama dengan data pelanggan maka prototype axis $\mathrm{X}$ akan bekerja menuju tempat penyimpanan barang yang sudah ditentukan oleh sistem untuk 
Majalah Ilmiah Teknologi Elektro, Vol. 19, No. 2, Juli - Desember 2020

DOI: https://doi.org/10.24843/MITE.2020.v19i02.P19

261

mengambil barang belanjaan dari pelanggan, lalu axis $\mathrm{X}$ akan bergerak ke tempat pengambilan barang dan prototype akan menunggu sampai pelanggan mengambil barang belanjaannya. Jika pelanggan sudah mengambil barang belanjaannya maka axis $\mathrm{X}$ akan kembali ke posisi stand by alat.

1) Uji coba pengambilan barang dari ruang penyimpanan

Pada pengujian pengambilan barang dari ruang penyimpanan, dilakukan untuk mengetahui apakah alat mampu mengambil barang yang disimpan pada ruang penyimpanan untuk diambil dan menuju titik pegambilan barang untuk dapat diambil oleh pembeli. Hasil Uji coba pengambilan barang dari ruang penyimpanan dapat dilihat pada tabel 7 berikut.

TABEL VII

UJI COBA PENGAMBILAN BARANG DARI RUANG PENYIMPANAN

\begin{tabular}{|c|c|c|c|c|c|c|c|c|c|c|c|}
\hline \multirow[t]{2}{*}{$\begin{array}{l}\text { Kode } \\
\text { Ruan } \\
\text { g }\end{array}$} & \multicolumn{2}{|c|}{$\begin{array}{l}\text { Ambil } \\
\text { Barang } \\
\text { Ruang } 1 \\
\end{array}$} & \multicolumn{2}{|c|}{$\begin{array}{l}\text { Ambil } \\
\text { Barang } \\
\text { Ruang 2 } \\
\end{array}$} & \multicolumn{2}{|c|}{$\begin{array}{l}\text { Ambil } \\
\text { Barang } \\
\text { Ruang } 3 \\
\end{array}$} & \multicolumn{2}{|c|}{$\begin{array}{l}\text { Ambil } \\
\text { Barang } \\
\text { Ruang 4 }\end{array}$} & \multicolumn{2}{|c|}{$\begin{array}{l}\text { Menuju titik } \\
\text { pengambila } \\
\mathrm{n}\end{array}$} & \multirow[t]{2}{*}{ Keterangan } \\
\hline & $\begin{array}{l}\mathbf{Y} \\
\mathrm{a}\end{array}$ & Tidak & $\begin{array}{l}\mathbf{Y} \\
\mathbf{a}\end{array}$ & Tidak & \begin{tabular}{l|}
$\mathbf{Y}$ \\
$\mathbf{a}$
\end{tabular} & Tidak & $\begin{array}{l}\mathbf{Y} \\
\mathbf{a}\end{array}$ & Tidak & Ya & $\begin{array}{l}\text { Tida } \\
\mathbf{k}\end{array}$ & \\
\hline 001 & $\checkmark$ & & & & & $\checkmark$ & & $\checkmark$ & $\checkmark$ & & Berhasil \\
\hline 002 & & $a^{2}$ & $\checkmark$ & & & $\begin{array}{ccc}r \\
\end{array}$ & & 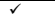 & $\checkmark$ & & Berhasil \\
\hline 003 & & 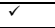 & & 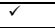 & $r$ & & & 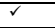 & $\checkmark$ & & Berhasil \\
\hline 004 & & 2 & & $v^{2}$ & & $\checkmark$ & $\checkmark$ & & $\checkmark$ & & Berhasil \\
\hline
\end{tabular}

Seperti yang ditampilkan pada tabel 7, ketika kode pengambilan barang adalah 001, maka alat akan mengambil barang pada ruangan 1 . Ketika kode pengambilan barang adalah 002 maka barang akan mengambil barang pada ruang 2. Ketika kode pengambilan barang adalah 003, maka alat akan mengambil barang pada ruang 3 dan ketika kode pengambilan barang adalah 004 maka alat akan mengambil barang pada ruang 4. Pada empat percobaan tersebut ketika barang diambil dari ruang penyimpanan, alat juga berhasil menuju titik pengambilan barang. Dari hasil uji coba diatas dapat disimpulkan bahwa percobaan pengambilan barang dari ruang penyimpanan dapat dikatakan berhasil.

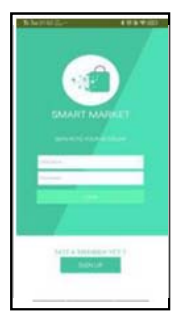

(a)

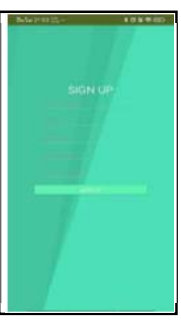

(b)

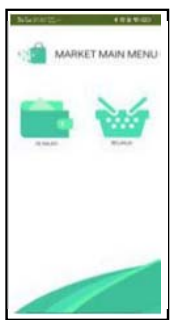

(c)

Gambar 11 (a) Halaman depan aplikasi smart market, (b) Halaman sign up aplikasi smart market, (c) Halaman utama smart market

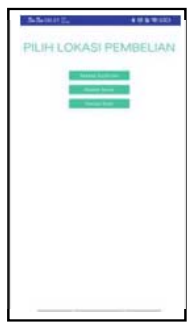

(a)

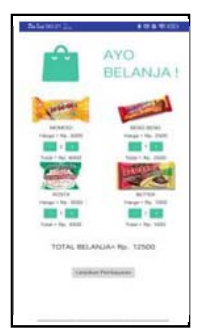

(b)

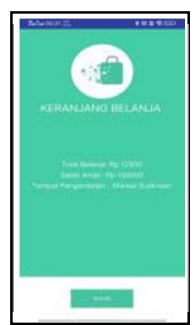

(c)

Ida Ayu Sri Sinta Anjani : Rancang Bangun isitem Minimarket...

p-ISSN:1693 - 2951; e-ISSN: 2503-2372

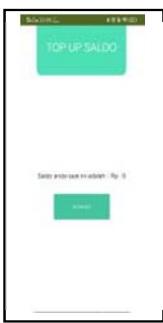

(a)

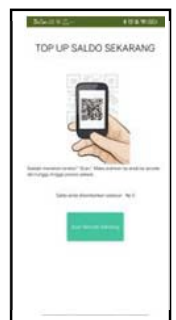

(b)

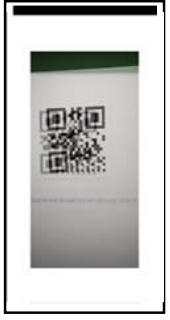

(c)

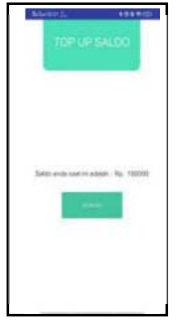

(d)
Gambar 13 (a) Tampilan saldo sebelum top up, (b) Tampilan halaman top up, (c) Melakukan Scan barcode voucher, (d) Tampilan saldo setelah top up.

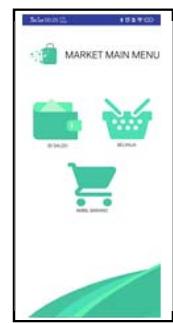

(a)

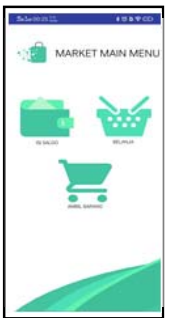

(b)

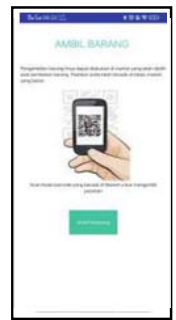

(c)

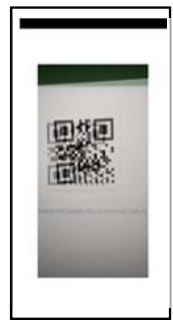

(d) pembelanjaan, (b) Tampilan pengambilan barang,(c) Tampilan scan barcode alat, (d) Tampilan setelah scan barcode.

E. Pengujian dan Pembahasan Konsumsi Daya

Pengujian dan Pembahasan Konsumsi Energi yang digunakan pada minimarket otomatis dilakukan dengan tujuan untuk mengetahui energi listrik dikonsumsi oleh alat. Hasil pengujian dapat dilihat pada tabel 9 .

Berdasarkan tabel IX, pada pengujian konsumsi daya alat minimarket otomasis dalam keadaan standby adalah sebesar 2,26 Watt . Konsumsi daya pada saat alat minimarket otomatis dalam keadaan bergerak dimana motor wiper dan motor power window bergerak adalah sebesar 106,37 Watt. Konsumsi daya pada alat minimarket otomatis dalam keadaan servo makanan bergerak adalah sebesar 48,1 Watt. Arus yang yang terbaca pada ampere meter sudah mendekati arus yang tertera pada datasheet dimana pada arduino mengeluarkan arus sebesar $40 \mathrm{~mA}$ untuk I/O pin[21], ESP sebesar $100 \mathrm{~mA}$ [22], Ir sensor sebesar $200 \mathrm{~mA}$ [23], motor power window sebesar 3 A[24], dan motor wiper sebesar 5 A [25]. 
TABEL IX

KONSUMSI DAYA

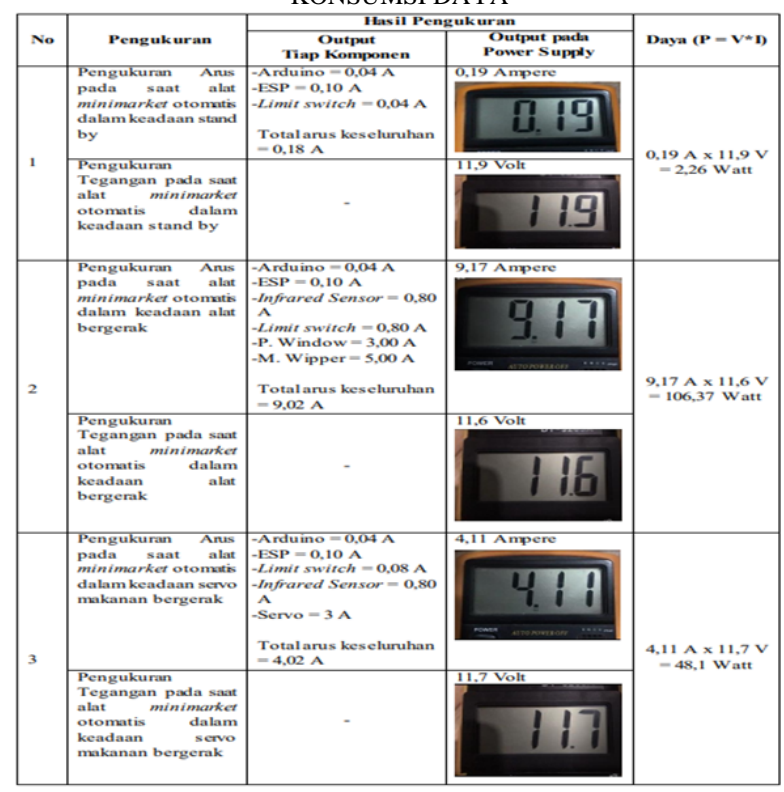

\section{KESIMPULAN}

Sistem yang dirancang pada penelitian ini menggunakan arduino mega dan ESP8266 sebagai mikrokontoler, limit switch sebagai sensor posisi, ir sensor sebagai sensor jarak, servo sebagai motor penggerak makanan, motor power window sebagai penggerak axis $\mathrm{x}$, dan motor wiper sebagai penggerak axis y. Alat akan melakukan pengambilan barang dan menyimpan barang yang dipiih ke ruang penyimpanan setelah pembeli melakukan pembayaran pada aplikasi.

Aplikasi android yang dirancang dapat melakukan komunikasi dengan alat dengan jaringan cloud dimana data pelanggan dan pembelian disimpan di firebase sebagai database. Arduino dan ESP8266 dapat melakukan komunikasi secara serial dimana arduino berfungsi melakukan pengontrolan dan ESP8266 berfungsi untuk jembatan antara arduino mega dengan database.

\section{REFERENSI}

[1] Miranti, Miranti (2019) Analisis Dampak Kehadiran Minimarket Terhadap Omset Pedagang Warung Kelontong Di Jalan Manuruki Makassar. Diploma thesis, Universitas Negeri Makassar. Tersedia pada : http://eprints.unm.ac.id/15054/

[2] Destiana, Destiana(2019). Pengaruh Teknologi Informasi Berbasis Android (Smartphone) Dalam Pendidikan Industry 4.0. Universitas PGRI Palembang. Tersedia pada: https://jurnal.univpgripalembang.ac.id/index.php/Prosidingpps/article/view/2528

[3] RAHARJO, Reza Haditya \& SETIAWAN, Achma Hendra (2015) Analisis Pengaruh Keberadaan Minimarket Modern Terhadap Kelangsungan Usaha Toko Kelontong Di Sekitarnya (Studi Kasus Kawasan Semarang Barat , Banyumanik, Pedurungan Kota Semarang). Undergraduate thesis, Fakultas Ekonomika dan Bisnis.

[4] Dewi, D. S. (2020). Dampak keberadaan Pasar Modern terhadap pendapatan para Pedagang Pasar Tradisional (Studi kasus di Desa Tanggul Angin Kecamatan Punggur)(Doctoral dissertation, IAIN Metro).

[5] Kawilarang J,A,Y,K., Sarah Sambiran, Alfon Kimbal. (2020). Dampak Kebijakan Perizinan Minimarket Terhadap Usaha Kecil Di Kecamatan Kawangkoan Dan Kawangkoan Barat. Jurnal Ekskusif. Vol 2(5), pp 110. Tersedia pada : https://ejournal.unsrat.ac.id/index.php/jurnalekseku tif/article/view/29647/28716
[6] Dewaweb.com. 2018. Pengertian Internet,Sejarah Dan Perkembangannya. [Online]. Tersedia pada : https://www.dewaweb .com/blog/pengertian-internet/

[7] Hasiholan, C., Primananda, R., \& Amron, K. 2018. Implementasi Konsep Internet $\mathrm{Og}$ Things Pada Sistem Monitoring Banjir Menggunakan Protokol Mqtt. Universitas Brawijaya, 2(12), pp. 61286132. Tersedia Pada: http://j-ptiik.ub.ac.id/index.php/jptiik/article/download/3529/1389

[8] Sasmoko, D., \& Wicaksono, Y. A. (2017). Implementasi Penerapan Internet Of Things (Iot) Pada Monitoring Infus Menggunakan Esp 8266 Dan Web Untuk Berbagi Data. Jurnal Ilmiah Informatika, 2(1), 90-98.

[9] [5] M. Wicaksono, "Implementasi Modul Wifi Nodemcu Esp8266 Untuk Smart Home”, Komputika, vol. 6, no. 1, Sep. 2017. Tersedua pada : https://ojs.unikom.ac.id/index.php/komputika/art icle/view/339

[10] Hakim, D. P. A. R., Budijanto, A., \& Widjanarko, B. (2018). Sistem Monitoring Penggunaan Air Pdam Pada Rumah Tangga Menggunakan Mikrokontroler Nodemcu Berbasis Smartphone Android. Jurnal IPTEK, 22(2), 9-18.

[11] Arranda, Dionysius F. 2017. Kontrol Lampi Ruangan Berbasis Web Menggunakan Esp8266 Esp8266. Stmik Akakom Yogyakarta. Tersedia pada : http://eprints.akakom.ac.id/4904/

[12] son, m. (2018). Pengembangan Mikrokontroler Sebagai Remote Control Berbasis Android. Jurnal teknik informatika, 11(1), 67-74

[13] Septryanti, A., \& Fitriyanti, F. (2017). Rancang Bangun Aplikasi Kunci Pintu Otomatis Berbasis Mikrokontroler Arduino Menggunakan Smartphone Android. Computer Engineering, Science and System Journal, 2(2), 59-63.

[14] Suardiana, I., Agung, I., \& Rahardjo, P. Rancang Bangun Sistem Pembacaan Jumlah Konsumsi Air Pelanggan Air Pdam Berbasis Mikrokontroler. Universitas Udayana, 16(1), pp 31-40. Tersedia pada : https://ojs.unud.ac.id/index.php/JTE/article/view/21576/17314

[15] Chaniago, D. S. (2019). Perancangan Dan Implementasi Sistem Absensi Cerdas Berbasis Arduino Mega. J-Sisko Tech (Jurnal Teknologi Sistem Informasi dan Sistem Komputer TGD), 2(2), 50-57.

[16] Susanti, E., Triyono, J., \& Pi, R. (2016). Pengembangan Sistem Pemantau Dan Pengendali Kendaraan Menggunakan Raspberry Pi Dan Firebase. Jurnal Informatika, 1, 144-153.

[17] Sanad, E., Achmad, A., \& Dewiani, D. 2018. Pemanfaatan Realtime Database Di Platform Firebase Pada Aplikasi E-Tourism Kabupaten Nabire. Tersedia pada : http://cot.unhas.ac.id/journals/index.php/jpe/ article/view/123

[18] Gunadi, G. (2020). Rancang Bangun Aplikasi Media Pembelajaran Mengenal Nama Hewan Dalam Dua Bahasa Berbasis Android Menggunakan Thunkable. Infotech: Journal of Technology Information, 06(1), 35-42.

[19] Mahaputra, I., Agung, I., \& Jasa, L. 2019. Rancang Bangun Sistem Keamanan Sepeda Motor Dengan Gps Tracker Berbasis Mikrokontroler Dan Aplikasi Android. Tersedia pada : https://ojs.unud.ac.id/index.php/JTE

[20] Djuni H, I., Agung, I., Pramaita, N., \& Sugiri, M. 2015. Pembuatan Prototype Sistem Pengendali Lampu Rumah Dengan Perangkat Mobile Android. Universitas Udayana, vol 14(2), pp 22-26

[21] Atmel, 2004, Datasheet Arduino Mega. Tersedia pada : http://eprints.polsri.ac.id/4598/8/File\%20VIII \%20\%28Lampiran\%29.pdf

[22] Espressif, 2020, Datasheet ESP8266. Tersedia pada : https://www.espressif.com/sites/default/files/documentation/0aesp8266ex_datasheet_en.pdf

[23] Electronicshub. 2018. Infrared Sensor. Tersedia pada : https://www.electronicshub.org/ir-sensor/.

[24] Rebeck. Datasheet. Motor Power Window HY-2750B. http://www.rebeck-motor.com/HY-2750B.htm.

[25] Oslv. Datasheet. GEARMOTOR FOR WINDSHIELD WIPERS MRT62-43. Tersedia pada https://www.oslv.com/uploads/model_10/.files/25 item_29.pdf. 